in his message published in Nature of May 5. He also pointed out that scientific workers generally have still a special part to play in the Festival. They alone can work for the better relationship between science and the community - for wider understanding of the methods and purpose of science. The achievement of this understanding will be an important step towards the fulfilment of the prayer with which the King concluded his address, that "the vast range of modern knowledge .. . may be turned from destructive to peaceful ends, so that all peoples, as this century goes on, may be lifted to greater happiness".

\section{Chemical Engineering at University College,} London: $\quad$ Prof. H. E. Watson

Prof. H. E. Watson will retire from the Ramsay chair of chemical engineering in University College, London, at the end of the present session. Educated at Marlborough and University College, where he came under the influence of Sir William Ramsay, Prof. Watson had a most distinguished college career. Awarded an 1851 Exhibition in 1909, he gained further experience in research in the Universities of Berlin, Geneva and Cambridge, working for a time in the Cavendish Laboratory, Cambridge. In 1911 he was selected by his former teacher, Dr. M. Travers, who had recently been appointed director of the Indian Institute of Science, Bangalore, to be assistant professor of inorganic and physical chemistry. This post he held until 1916 when, on the retirement of Dr. Travers, he was appointed to the chair. Although Prof. Watson's main interests lay in physical chemistry, to which subject he has made valuable contributions, he collaborated with his colleague, Prof. J. J. Sudborough, in the study of Indian natural products likely to prove of economic value. With their students they published a long series of important papers on Indian vegetable and essential oils. One outcome of this work was the establishment of the Mysore Government Factory for the distillation of sandalwood oil. Many of Prof. Watson's students now occupy important positions in Indian universities and industry. On returning to Great Britain in 1934, Prof. Watson was appointed to his present chair. With the outbreak of the Second World War in 1939, his services were placed at the disposal of the Admiralty, and on his return to the College in 1945 he was faced with the problem of rebuilding and refitting his laboratory, which had been destroyed by enemy action. There is little doubt that under more favourable conditions Prof. Watson would have made an even more valuable contribution to the training of chemical engineers than he has done.

\section{Mr. M. B. Donald}

Mr. Maxwell Bruce Donald, who has been appointed to succeed Prof. Watson, was born in 1897 and educated at Felsted School. He entered the Royal College of Science, London, in 1914 ; but his university career was interrupted by the First World War, in which he served in France as a lieutenant in the Royal Artillery. Returning to London at the end of the War, Mr. Donald obtained the associateship of the College with a first class in chemistry and was awarded a Yarrow Scholarship for study in the United States, where he worked at the Massachusetts Institute of Technology and obtained his first taste for chemical engineering. He was elected an associate member of the newly formed Institution of Chemical Engineers in 1923, and, after two years of teaching, he spent three years in Chile investigating problems of nitrate production. In 1931 he was appointed a lecturer, and in 1947 reader, in chemical engineering at University College, London. Mr. Donald is probably best known to his wide circle of friends as the honorary secretary during 1937-49 of the Institution of Chemical Engineers; he is now a vice-president of the Institution, a member of council of the Royal Institute of Chemistry, member of the Chemical Council, director of the Bureau of Abstracts, chairman of the Maximum Permissible Working Stress Committee of the British Standards Institution, and a member of many other committees. In these varied capacities he has rendered services of the greatest value to chemical engineering, especially on tho educational side. $\mathrm{He}$ was mainly responsible for drafting the scheme for an undergraduate course in chemical engineering, which forms the basis of teaching in many universities throughout the British Commonwealth, and has more recently prepared a much-wanted syllabus for higher national certificates. These activities have not prevented his writing numerous scientific papers and reports of considerable importance, including two recent memoirs of a historical nature. In his new post Mr. Donald will have ample opportunity to continue this good work, and the profession will look forward to his help and guidance in the future.

\section{Applied Mathematics at Queen's University, Belfast: $\quad$ Mr. D. R. Bates}

Mr. D. R. Bates, at present reader in physics in University College, London, has been appointed to the chair of applied mathematies in Queen's University, Belfast. Mr. Bates is a graduate of Queen's University, where in 1937 he took the degree of B.Sc. with first-class honours in mathematical physics and experimental physies, and in 1938 the degree of M.Se. in mathematical physics. After a short period as a research student at University College, London, under Prof. H. S. W. Massey, he was engaged in research for the Admiralty until 1945. Sinee then, apart from a visit to the United States in 1950, he has been again at University College. Mr. Bates's research has been mainly directed to the application of quantum mechanics to the study of atomic structure and the rates of atomic processes, and in particular to those problems which have a bearing on the properties of the upper atmosphere and similar diffuse systems. He has published a large number of important papers on these subjects and is a recognized authority on the physics of the ionosphere, as well as an important contributor to astrophysical subjects. In particular, his paper on the "Intensities of Spectral Lines" should prove of much value to astrophysicists. During the Second World War Mr. Bates was concerned mainly with the defensive and offensivo aspects of sea mining warfare, and his work led to much economy in the difficult technique of design of mine mechanisms for resisting the shocks inherent in mine laying.

\section{Samuel George Morton (1799-1851)}

A centuhy ago, on May 15, 1851, Samuel George Morton, physieian and naturalist, died in Philadelphia at the age of fifty-two. Born in 1799, he graduated M.D. at the University of Ponnsylvania in 1820 , and, after studying in Europe, obtained the M.D. of the University of Edinburgh three years lator. In 1839 he was elected to the professorship of anatomy in Pennsylvania College, and his substantial "Human 